\title{
Dismissal protection in Germany
}

\author{
dr. Bernd Waas*
}

\section{Introduction}

The following is a brief overview of the main elements of protection against dismissal in Germany. However, only ordinary dismissals will be dealt with, while legal issues of extraordinary (summary) dismissal and mass redundancy will be left out. In Section 2, the basics of the dismissal law system will be explained. Section 3 will discuss, in particular, the possible reasons for dismissal and the substantive requirements. Section 4 deals with the procedural aspects, while section 5 explains, in short, how the payment during sickness is organized. The remedies are dealt with in Section 6 . Section 7 shortly discusses the social security aspects during unemployment. Section 8 concludes.

Although there is a broad protection against dismissal in Germany, based on a large number of laws, but also on judge-made law, the Dismissal Protection Act is the linchpin of statutory protection against dismissal. Here, the central question is whether the termination can be considered 'socially justified'.

\section{Basics of the dismissal law system}

\subsection{The importance of constitutional law}

In Germany, freedom of profession as enshrined in Article 12(1) of the German Constitution, the Basic Law (Grundgesetz, GG), requires the state to provide minimum protection against dismissals for each and every employee. ${ }^{1}$ There are numerous individual laws, in particular the Dismissal Protection Act (Kündigungsschutzgesetz, $K S \operatorname{sh} G)$, which protects employees in case of dismissal. However, the KSchG does not apply to all employees. The Federal Constitutional Court held some time ago that this was in conformity with the Constitution partly on the ground that, irrespective of statutory law, a certain level of dismissal protection exists for all employees under the so-called general clauses of civil law. ${ }^{2}$ According to the courts, a dismissal, for instance,

Bernd Waas is Chair of Labour Law and Civil Law under consideration of European and International Labour Law at Goethe-Universität.

1. See, for instance, Federal Constitutional Court of 24 April 1991 - 1 BvR $1341 / 90$.

2. Federal Constitutional Court of 27 January 1998 - 1 BvL 15. is void if it is contrary to public policy or amounts to socalled victimization. Moreover, dismissals may not violate the principle of good faith. In fleshing-out this extra-statutory dismissal protection, the courts apply the general clauses of civil law in light of freedom of profession, an exercise which illustrates the doctrine of German law that fundamental rights guaranteed under the Constitution are (indirectly) horizontally applicable to the relationship between private parties.

\subsection{The Dismissal protection Act (KSchG), other} laws, judge-made law

The KSchG is at the heart of the protection against dismissal. However, the scope of application of the law is, as mentioned, limited. First, dismissal protection is linked to a 'waiting period' within which the employer's power to terminate the employment relationship is not yet restricted by the KSchG. According to section 1(1) of the KSchG, the employment relationship in the same establishment or in the same company of the employer must have existed for more than six months. Second, according to section 23(1) sentence 3 of the KSchG, the law is largely applicable only to establishments with more than ten employees. This is based on, among other things, the assumption that greater flexibility in terms of human resources is required in small undertakings and that a particularly close personal cooperation which may exist in such undertakings would be endangered by excessive legal restrictions. ${ }^{3}$ It should, however, be noted that it is largely up to the employer to decide what should constitute a separate undertaking and which employees should belong to it. In this respect, the courts merely examine whether the employer's decision is an abuse of rights. ${ }^{4}$

In addition to the KSchG, there are numerous other laws that contain provisions on protection against dismissal, which makes the entire protection against dismissal quite confusing. For example, the German Works Constitution Act (Betriebsverfassungsgesetz), the Part-Time Work and Fixed-Term Employment Act (Teilzeit- und Befristungsgesetz), the Part-Time Employment for Older Employees Act (Altersteilzeitgesetz) and the Social Security Code (Sozialgesetzbuch VI) all contain provisions on the protection against dismissal. Apart from these individual laws that are linked either to a specific status of a person or to specific circumstances, protection against discriminatory dismissals has gained importance. Section 2(4) of the General Act on

3. See Federal Parliament Printing Matter 13/4612 of 10 May 1996.

4. Federal Labour Court of 28 October 2010 - 2 AZR 392/08; 19 July 2016 - 2 AZR 468/15; 2 March 2017 - 2 AZR 427/16. 
Equal Treatment (Allgemeines Gleichbehandlungsgesetz, $A G G$ ) provides that 'only the provisions regulating the protection against unlawful dismissal in general and in specific cases shall apply to dismissals'. According to the courts, this provision must be interpreted in conformity with EU law. This means that the prohibition of discrimination as laid down in the General Act on Equal Treatment must be taken into account when assessing whether a dismissal is 'socially justified' under the KSchG. Application of the General Act on Equal Treatment still raises a few questions. For instance, section 15(2) of the AGG provides for compensation in cases of discrimination while such a remedy is not available under the Dismissal Protection Act. Nevertheless, the courts hold that compensation is, at least in principle, also available in cases of discriminatory dismissals, even if they fall within the area of the Act on Dismissal Protection. ${ }^{5}$ If the Dismissal Protection Act is not applicable because either the statutory waiting period has not been fulfilled, or because the business is too small, dismissals must be evaluated directly on the basis of the AGG. $^{6}$

Beyond the statutory provisions, the case law of the courts must also be taken into account. As already mentioned, the courts have developed protection against dismissal outside the KSchG. The according judgemade rules, mostly based on the general clauses of civil law, apply to employees who are not covered by the KSchG. Even where the KSchG is applicable, the courts have never been content with applying the provisions contained therein, but have developed further principles instead against which terminations by the employer are to be measured. These principles have sometimes been taken up by the lawmaker when amending the KSchG and have to be observed in any event when applying it.

\section{Dismissal protection under the KSchG}

Section 1(1) of the KSchG reads as follows: 'Termination of the employment relationship with respect to an employee whose employment relationship has existed in the same establishment or enterprise without interruption for more than six months shall be legally invalid if it is socially unjustified'. According to section 1(2) sentence 1 , 'the termination shall be socially unjustified if it is not due to reasons relating to the person or conduct of the employee or to urgent operational requirements which prevent the employee's continued employment in this establishment'.

\subsection{Possible reasons}

Accordingly, a dismissal can, in principle, be based on person, conduct or operational requirements. In addition to the reasons, the courts, in principle, accept two other reasons that do not easily fit into the statutory scheme: dismissals that are based on a mere suspicion (of serious misconduct) und dismissals due to outside pressure. Dismissals of the former type are lawful if a number of requirements is met. According to case law, a dismissal on suspicion may be justified if there is a reasonable suspicion based on objective facts which affects the trust required for the continuation of the employment relationship and if the employer makes all reasonable efforts to clarify the facts, in particular if he/she gives the employee the opportunity to comment on the allegation. ${ }^{7}$ Dismissals of the latter type occur when a third party demands the dismissal of a certain employee under threat of disadvantages for the employer, although there are no circumstances in the employee's behaviour or person that would objectively be suitable as grounds for dismissal. However, such dismissals can only be considered if the employer has protected the employee and has done everything reasonable, even if unsuccessfully, to dissuade the third party from pushing him/her towards dismissal. ${ }^{8}$

There are no absolute grounds for termination. No dismissal, in other words, can be regarded as automatically lawful. Even if, for instance, misconduct is punishable, the courts have held that a related termination of the employee is not automatically lawful. According to case law, even such cases require a comprehensive, caseby-case assessment and a balancing of the interests of both parties concerned..$^{9}$ On the other hand, no dismissal can be regarded as automatically unlawful since an absolute prohibition of termination would violate the constitutional principle of proportionality which requires that the employer must be able to terminate the employment relationship, at least in extreme cases.

\subsection{Substantive requirements}

In principle, any dismissal must meet the requirements resulting from the principles mentioned above, which have been developed by the courts, but are also found in part in the provisions of the KSchG.

The first of these is the co-called 'prognosis principle'. Under this principle, the justification of a termination primarily depends on the future effects of past or present events. In assessing the lawfulness of dismissal, the key question is always whether that event was so detrimental that a fruitful continuation of the contract in the future appears to be impossible. From this perspective, past incidents are only relevant if they indicate a future impairment of the employment relationship. Second, the principle of proportionality applies. Under this principle, dismissal is regarded to be the most
Federal Labour Court of 2 March 2017 - 2 AZR 698/15.
Federal Labour Court of 18 July 2013 - 6 AZR 420/12.
Federal Labour Court of 10 June 2010 - 2 AZR 541/09. 
extreme measure (ultima ratio) that can only be lawfully considered by the employer if there is no possibility for further employment. ${ }^{10}$ Though the principle stems from public law, in the view of the courts it can also be applied to the field of dismissal protection law. Some of the provisions of the KSchG can also be regarded mirroring the principle of proportionality. This applies, in particular, to section 1(2) sentences 2 and 3 of the $\mathrm{KSchG}$, which refer the employer to means that preclude termination, namely continued employment at another workplace in the company, if necessary after retraining the employee or modifying working conditions. ${ }^{11}$ Finally, the principle of balancing the interests of the parties applies. As regards extraordinary dismissals, the need for such balancing is explicitly foreseen in the law. ${ }^{12}$ According to the courts, it also applies to cases of ordinary dismissal. ${ }^{13}$ The main area of application are dismissals related to either the person or the conduct of the employee. A case in point is a dismissal that is connected to the sickness of the employee. In such cases, the labour courts must take into account the adverse economic and operational consequences for the employer, but also, for example, the employee's family circumstances, in particular his or her maintenance obligations, and weigh the relevant interests against each other. ${ }^{14} \mathrm{~A}$ balancing of interests must also take place if a dismissal is the result of the employee's behaviour. Among the aspects to be considered in this context are the consequences for the employer; a possible risk of repetition, the nature, gravity and frequency of the alleged breaches of duty, including the degree of culpability; past behaviour of the employee and possible contributory negligence of the employer; age of the employee, length of service and maintenance obligations.

\subsection{A closer look at the main reasons}

What does this mean for the review of a dismissal based on person, conduct or operational requirement? As regards the first, a case in point is illness. Though sickness as such does not constitute a sufficient reason for termination, non-performance or poor performance of service as well as the resulting significant impairment of the employer's business and economic interests on account of the employee's sickness may justify the termination of the employment relationship. ${ }^{15}$ Like any other dismissal for personal reasons, a dismissal due to illness must be evaluated in three stages: first, a negative prognosis with regard to the employee's future health status is required. Second, the court must examine whether the employee's (predicted) absence will result in a significant impairment of the employer's interests,

10. See, for instance, Federal Labour Court of 30 May 1978 - 2 AZR $630 / 76$.

11. See, for instance, Federal Labour Court of 26 March 2015 - 2 AZR $417 / 14$.

12. See section 626(1) of the Civil Code (Bürgerliches Gesetzbuch, BGB).

13. See Federal Labour Court of 7 October 1954 - 2 AZR 6/54

14. Federal Labour Court of 20 January 2000 - 2 AZR 378/99.

15. Federal Labour Court of 26 September 1991 - 2 AZR 132/91. either operationally or financially. ${ }^{16}$ Finally, the court must determine whether that impairment will result in an unacceptable operational and economic burden for the employer. ${ }^{17}$ In applying these standards, the courts differentiate between different groups of cases (dismissal for frequent short-term illnesses and dismissal due to long-term illness, in particular).

Dismissals can, in principle, also be based on 'conduct'. As a rule, the negative prognosis necessary to lawfully dismiss an employee is only possible following a prior warning: if the employee was duly warned but continues to violate his/her contractual duties, it can generally be assumed that further violations will take place in the future. ${ }^{18}$ At the same time, the warning gives expression to the principle of proportionality, since a dismissal is to be regarded as disproportionate if there are other suitable and less drastic means and measures available to the employer - such as, in particular, a warning - to avoid future disturbances. ${ }^{19}$ In principle, every conduct-related dismissal requires a prior warning to have been issued. Only if it is either obvious that a change in the employee's behaviour is not to be expected in the future, or if the breach of duty is so serious that it must be considered completely unreasonable, even from the employee's point of view, may the employer terminate an employee without prior warning. ${ }^{20}$

Lastly, a dismissal can, in principle, be based on 'urgent operational requirements that prevent the employee from continuing to work in the company'. This means that there are at least two requirements for dismissals based on business reasons. First, the need for the work must have decreased. Second, operational requirements must exist, which prompt the termination and which are 'urgent'; in general, a dismissal for business reasons must be proportionate. A third requirement arises from section 1(3) of the KSchG which provides that a dismissal for operational reasons is socially unjustified if the employer has not or has insufficiently considered the duration of the employee's seniority, age, maintenance obligations and severe disability when selecting the employee'. With regard to the first requirement (reduced need for work), the courts recognize that all terminations for operational reasons are ultimately based on business decisions. In doing so, they assume that these decisions are subject to only limited judicial review. Essentially, entrepreneurial decisions can only be examined to determine whether they are 'obviously unobjective, unreasonable or arbitrary'. ${ }^{21}$ The second requirement is that the dismissal must be proportionate. The question to be answered in this regard is whether the dismissal could have been avoided by other

\footnotetext{
16. See, for instance, Federal Labour Court of 16 February $1989-2$ AZR $299 / 88$.

17. See, for instance, Federal Labour Court of 20 November $2014-2$ AZR 755/13.

18. Federal Labour Court of 23 June 2009 - 2 AZR 103/08

19. Federal Labour Court of 23 January 2014 - 2 AZR 638/13.

20. Federal Labour Court of 20 November 2014 - 2 AZR 651/13

21. Federal Labour Court of 26 September 2002 - 2 AZR 636/01.
} 
measures. ${ }^{22}$ For instance, an operational requirement is not 'urgent' if, instead of the dismissal of one or more employees for operational reasons, overtime worked by other employees in the company on a permanent basis could be reduced. Moreover, dismissing an employee for business reasons is not permitted if the possibility of further employment exists either within the establishment or the company. ${ }^{23}$ Finally, a 'social selection' is required under section $1(3)$ of the KSchG. ${ }^{24}$ The employer must first identify the employees among whom the social selection will take place. Subsequently, these workers must be categorized in a sequence according to certain social aspects (age, length of service, support obligations, disability). In a last step, those employees whose continued employment is in the legitimate operational interest, in particular because of their knowledge, skills and achievements or to ensure a balanced personnel structure of the establishment, can be excluded from the social selection. The determining criteria are length of service, age, maintenance obligations and 'severe disability'. According to section 1(3) sentence 1 of the KSchG, the employer must consider the social aspects 'sufficiently'. Thus, a certain margin of appreciation' exists. Under section 1(4) of the KSchG, a collective agreement (concluded by a trade union on the employee side) or a works agreement (concluded by a works council) may determine how the social aspects must be weighted in relation to each other. If such a collective agreement exists, the assessment may only be reviewed for gross errors (for instance, an unsystematic formation of age groups). Accordingly, the partners to the agreement have some leeway. Finally, under section 1(5) of the KSchG, if termination is due to a socalled operation change in business pursuant to section 111 of the Works Constitution Act (Betriebsverfassungsgesetz, BetrVG $)^{25}$ and the employees to be terminated are designated by name in a so-called reconciliation of interests between the employer and the works council, it is presumed that the termination is subject to urgent operational requirements within the meaning of section 1(2) of the KSchG. Moreover, the social selection of employees can only be assessed for gross errors. ${ }^{26}$ This is based on the legislator's consideration that the

22. See, for instance, Federal Labour Court of 26 March 2015 - 2 AZR $417 / 14$.

23. See section 1(2) sentences 1 and 2 lit b) of the KSchG.

24. See Federal Labour Court of 27 June 2019 - 2 AZR 50/19: 'The regulatory objective of social selection within the meaning of section 1(3) of the KSchG is to contribute to a fair distribution of the remaining jobs among the employees (...). In principle, the employee who is least dependent on the employment relationship is to be dismissed'.

25. Pursuant to section 111 sentence 3 , the following shall be deemed to be operational changes in business: restriction and closure of the entire operation; relocation of the entire operation or of significant parts of the operation; merger with other operations or the division of operations; fundamental changes in the organization of the operation, the purpose of the operation or the operating facilities; introduction of fundamentally new working methods and production processes.

26. Section 1(5) sentences 1 and 2 of the KSchG. participation of the works council provides a high guarantee for the correctness of the selection made. ${ }^{27}$

3.4 Assessment by the public authority or court In general, the termination is only subject to subsequent review which is carried out by the courts. This can be interpreted as that German employment protection law does not want to patronize the employee. The employee is free to accept even an objectively inadmissible termination. On the other hand, it can be considered problematic that terminations by the employer in many cases remain unchallenged.

In Germany, preventive protection against dismissal exists only in exceptional cases. Thus, section 167(1) of the Social Code Book IX (Sozialgesetzbuch IX, SGB $I X)$, with regard to severely disabled persons provides for a procedure according to which the employer, in the event of personal, behavioural or operational difficulties that may jeopardize the employment relationship, must, among other things, involve the representative body for severely disabled persons (Schmerbehindertenvertretung pursuant to section 178 SGB IX) as well as the Integration Office. More specifically, an obligation exists to discuss with them all the possibilities and all the assistance available for counseling and possible financial benefits, with which the difficulties can be eliminated and the work or other employment relationship can be continued as permanently as possible. Section 167(2) SGB IX concerns the more specific case of so-called operational integration management, which, however, applies to all employees and is of particular importance in the case of dismissals due to illness. According to section $167(2)$ sentence 1 , if employees are unable to work continuously or repeatedly for more than six weeks within a year, the employer must clarify with the competent works council, and also with the representative body for severely disabled persons in the case of severely disabled persons, with the consent and participation of the person concerned, the options for overcoming the inability to work as far as possible and with which services or assistance renewed inability to work can be prevented and the job maintained. If necessary, the company physician or company doctor shall be consulted.

Only in a few cases is protection against dismissal implemented not by private law but by public law (usually in the form of a prohibition of dismissal, in principle, and subject to permission). The main cases of this protection against dismissal under public law are the regulations on the rehabilitation and participation of disabled persons, maternity protection, parental allowance and care time law and protection against dismissal in the event of mass redundancies. The example of the Federal Parental Allowance and Parental Leave Act (Bundeselterngeld- und Elternzeitgesetz, BEEG) may illustrate this point. According to section 18(1) of the BEEG, the employer may not terminate the employ-

27. See, for instance, Federal Labour Court of 19 July 2012 - 2 AZR $386 / 11$. 
ment relationship as of the date on which parental leave was requested. During parental leave, the employer may not terminate the employment relationship either. In exceptional cases, the termination may be declared admissible. The declaration of admissibility shall be made by the supreme state authority responsible for occupational health and safety or an authority designated by it. An exceptional case exists, in particular, if a company is shut down. In addition, serious misconduct may constitute an exceptional case if it must be considered unreasonable that the employment relationship could be continued. ${ }^{28}$

\section{Procedural aspects and terms}

\subsection{Involvement of works councils}

According to section 102(1) of the Works Constitution Act (Betriebsverfassungsgesetz, BetrVG), the works council must be heard before each dismissal. The hearing is not intended to enable the works council to independently review the legal effectiveness of the intended termination, but only to provide the opportunity to influence the employer's decision-making. In appropriate cases, the works council's statement in the hearing procedure is intended to contribute to the fact that the notice of termination is not given at all. Obviously, section 102 only applies if a works council exists, which often is not the case, especially in small companies where, for various reasons, works councils are often not elected. That the works council must be heard before each dismissal means that any dismissal (including extraordinary dismissals) triggers the right of the works council. Section 102 does not only apply to mass redundancies, ${ }^{29}$ but also to the dismissal of a single employee. Moreover, it applies to all employees employed in a company, even if they do not (yet) enjoy dismissal protection under the KSchG. ${ }^{30}$ The works council must be heard before the dismissal since it must have the opportunity to change the employer's mind. According to case law, the extent of information to be provided by the employer must be assessed in light of the purpose of section 102. The communication is only sufficient for that purpose if the works council is fully

28. See, for instance, Administrative Court Munich of 5 November 2019 12 ZB 19.1222 (accounting fraud by a payroll clerk) according to which an exceptional case can only be assumed 'if extraordinary circumstances justify that the interests of the employee claiming parental leave, which are generally regarded by law as having priority, take a back seat to the interests of the employer in the termination of the employment relationship'.

29. Federal Labour Court of 16 September $1993-2$ AZR 267/93. It should be noted that according to section 113 of the BetrVG so-called social plans are concluded between the employer and the works council. However, this does not prevent a trade union from concluding such agreements for its members. See Federal Labour Court of 24 April 2007 - 1 AZR 252/06 also affirming that the right to strike is by no means limited in this event.

30. See Federal Labour Court of 23 April 2009 - 6 AZR 516/08 aware of the situation. This means that the employer must not only communicate the reasons for dismissal, but also the termination date and notice period. ${ }^{31}$ The reasons for dismissal must be set out in detail by the employer in such a way that the works council can assess their soundness without having to carry out any additional investigation and must be able to determine whether it makes sense to raise concerns or to object to the termination. ${ }^{32}$ In the event of redundancy, the works council must be informed of the extent to which the job of the employee to be terminated will be discontinued. The works council can respond to the information by expressing concerns. If the employer is not convinced, he/she is free, however, to notify the employee of the termination of the employment relationship. In case of an ordinary dismissal, the works council can expressly oppose the dismissal if reasons to object exist in accordance with section 102(3) of the BetrVG. These reasons mostly have collective implications, which regularly are better understood by the works council than by the individual employee. For instance, there is reason to object if the employer has not (sufficiently) considered social aspects when selecting the employee to be dismissed, ${ }^{33}$ or if the person to be dismissed could be further employed at another workplace in the same establishment or in another establishment of the company. ${ }^{34}$ If the objection meets the formal requirements and is also made in a timely manner, it does not as such prevent the employer from giving notice. The employee, however, may make a claim for continued employment: according to section 102(5) sentence 1 of the BetrVG, if the works council has objected to a dismissal and if the employee has filed an action under the Dismissal Protection Act claiming that the employment relationship has not been terminated by the dismissal, the employer must, at the request of the employee, continue to employ him/her under the same working conditions until the conclusion of the dispute by a court decision that cannot be contested anymore. During this period, the original employment relationship continues to exist as it existed at the time when the notice period expired. The employee is actually to be employed with his/her previous activity. If the employer does not employ the employee, he is in default of acceptance. Section 102(1) sentence 3 of the BetrVG explicitly states that if the employer terminates the employment relationship without a prior hearing of the works council, the termination is ineffective. According to case law, the same applies, however, if the hearing of the works council was flawed. ${ }^{35}$ Any incorrect information of the works council, deliberately or not, is in other words, treated by the courts like non-information of the works council.

\footnotetext{
1. Federal Labour Court of 16 July 2015 - 2 AZR 15/15.

See Federal Labour Court of 23 October 2014 - 2 AZR 736

Section 102(3) no 1 of the BetrVG.

Section 102(3) no 3 of the BetrVG.

5. See, for instance, Federal Labour Court of 16 September $1993-2$ AZR 267/93.
} 


\subsection{Role of the courts}

Whether or not a termination is 'socially unjustified' under the KSchG must be determined by the courts. According to section 4 sentence 1 of the KSchG, if an employee claims that a termination is socially unjustified or otherwise ineffective, he/she must bring his/her claim before the court within three weeks of receipt of the written notice of termination at the latest. If the claim has not been lodged in time, the termination shall be deemed to be legally valid from the start (section 7 $\mathrm{KSchG}$ ). The procedural time limit, in other words, gives rise to a substantive exclusion period, the noncompliance of which results in the action brought by the employee being deemed to be unfounded (instead than not admissible). ${ }^{36}$

In dismissal protection proceedings, the burden of proof is shared between the employer and the employee. The burden of proof for the personal requirements of dismissal protection (applicability of the KSchG) lies, in principle, with the employee. ${ }^{37}$ The employer, on the other hand, bears the burden of proof regarding the reasons for the termination. ${ }^{38}$ With regard to the possibility of other employment, there is a so-called graded burden of proof: with regard to the lack of further employment opportunities, the employer initially meets his/her burden of proof by making the general assertion that there are no such employment opportunities. The employee then must explain how he/she envisages other employment. In view of the fact that the employee usually does not have an insight into the company organization, he/she does not have to name any specific workplaces, though. It is then up to the employer to explain and prove that this employment opportunity in reality is not available. ${ }^{39}$

In relation to costs, there are important differences from the rules of civil procedures. ${ }^{40}$ Court fees charged in standard proceedings before the labour court are considerably lower than for proceedings before the ordinary courts. ${ }^{41}$ Moreover, there is no requirement to pay court fees in advance. ${ }^{42}$ Finally, section $12 \mathrm{a}(1)$ of the Labour Court Act (Arbeitsgerichtsgesetz, ArbGG) provides that in first instance standard proceedings, the successful party is not entitled to compensation for their time or to reimbursement of the costs of legal representation. In practical terms, however, the impact of this rule is limited as trade unions and employer confederations often provide legal protection and representation to their members free of charge.

36. See, for instance, Federal Labour Court of 24 June 2004 - 2 AZR $461 / 03$.

37. Federal Labour Court of 20 February 2014 - 2 AZR 859/11.

38. Section 1(2) sentence 4 of the KSchG: "The employer has to prove the facts that cause the termination.".

39. See, for instance, Federal Labour Court of 24 May 2012- 2 AZR 62/11.

40. See for more details, B Waas, 'Germany' in M Ebisui, S Cooney and C Fenwick (eds); Resolving Individual Labour Disputes - A comparative overview (Geneva, ILO), 2016, p. 135.

41. See the Courts Fees Act (Gerichtskostengesetz, GKG), Annex 1 to section 3(2), Part 8.

42. Section 11 of the GKG.
In 2019 , a total of 328,713 actions were lodged with the labour courts. In 311,643 cases, the action was brought by an employee, trade union or works council. Dismissal was the subject matter of the action in 186,528 cases. Only 234,686 of all cases proceeded to a final judgment by the court. By contrast, actions were settled by way of a (mostly court-induced) compromise either in court or out-of-court settlements in 206,648 cases. $^{43}$

\section{Payment during sickness}

As already indicated above, illness can be a reason for dismissal if a significant impairment of the employer's business or operational interests is deemed to exist. The Federal Labour Court takes the view that in this context sickness pay can, in principle, also be taken into account when assessing whether a dismissal is socially justified. ${ }^{44}$ It should be noted, however, that sickness pay is limited in Germany. Section 3(1) sentence 1 of the Continued Remuneration Act (Entgeltfortzahlungsgesetz, EFZG) provides that if an employee is prevented from working due to incapacity to work as a result of illness for which he/she is not responsible, he/she shall be entitled to continued payment of remuneration by the employer for the period of incapacity to work up to a maximum of six weeks only. Only under exceptional circumstances, sickness pay is due for a longer period of time. ${ }^{45}$

In principle, continued payment of wages by the employer is therefore limited to six weeks. If the illness lasts longer, the employee has a claim against the health insurance fund for a so-called sickness benefit pursuant to sections 44 et seq. of Social Code Book V (Sozialgesetzbuch $\mathrm{V}, S G B V) .{ }^{46}$ The amount of the sickness benefit is, in principle, limited to $70 \%$ of regular pay (section 47(1) sentence 1 of SGB V).

\section{Remedies}

Section 1(1) of the KSchG explicitly states that a dismissal which is found to be 'socially unjustified' is

43. See for more details Waas, in: M. Ebisui, S. Cooney \& C. Fenwick, Resolving Individual Labour Disputes - A comparative overview, Geneva: ILO, 2016, p. 135.

44. See, for instance, Federal Labour Court of 6 September $1989-2$ AZR $19 / 89$.

45. See section 3(1) sentence 2: 'If the employee becomes incapacitated for work again as a result of the same illness, he shall not lose the entitlement under sentence 1 for a further period of not more than six weeks due to the renewed incapacity for work if 1 . he was not incapacitated for work as a result of the same illness for at least six months prior to the renewed incapacity for work or 2. a period of twelve months has expired since the beginning of the first incapacity for work as a result of the same illness'. It should also be noted that, in principle, the entitlement to continued remuneration ends with the termination of the employment relationship. This also applies in case of dismissal. See Federal Labour Court of 17 April 2002 - 5 AZR 2/01.

46. The health insurance fund is co-financed by employee and employer contributions. 
'legally ineffective', i.e. null and void. The assessment of the lawfulness of dismissal depends on the facts that existed at that particular time. ${ }^{47}$ As dismissal, if found unlawful, is eo ipso ineffective, no order for reinstatement is necessary.

Some particularities do exist, however. Since the reason for termination is determined at the time of termination, the dismissal is effective, even if the reason for termination unexpectedly disappears between receipt of the notice of termination and the expiry of the notice period. As it seems unfair in such cases for the employee to lose his/her job, the courts have 'created' a claim for reinstatement: an employee can claim reinstatement if 1 . the prognosis proves to be inaccurate after receipt of the notice of termination, but prior to the expiry of the notice period, 2 . the employer has not made any conflicting arrangements, ${ }^{48}$ and 3 . continuation of the employment relationship looks reasonable from the perspective of the employer. Moreover, a claim for reinstatement requires the dismissal to fall within the scope of application of the Dismissal Protection Act. ${ }^{49}$

As the consequence of an unlawful dismissal is its 'legal ineffectiveness', it can be said that dismissal protection aims to guarantee the (continued) existence of the employment relationship. ${ }^{50}$ It should immediately be added, however, that in practice, court proceedings end for the most part with a settlement, with the employee accepting the termination of his/her employment relationship against a severance payment. Moreover, section 9(1) of the KSchG limits the guarantee mentioned above: ${ }^{51}$ If the employment relationship has not been effectively terminated by a notice of termination, but the employee cannot be reasonably expected to continue the employment relationship, the court shall, at the employee's request, terminate the employment relationship and order the employer to pay the appropriate severance payment. ${ }^{52}$ The same decision shall be taken by the court at the request of the employer if grounds exist that do not give reason to expect further cooperation between the employer and the employee for the purposes of the enterprise. ${ }^{53}$ As far as executive employees are concerned, ${ }^{54}$ section $14(2)$ sentence 2 of the KSchG specifies that the request for a resolution of the employment relationship on the part of the employer does not

47. Federal Labour Court of 13 February 2008 - 2 AZR 543/06.

48. If, for example, he/she has already filled the job with a newly hired employee in the event of termination due to illness, the claim does not exist; see Federal Labour Court of 28 June 2000 - 7 AZR 904/98.

49. Federal Labour Court of 19 October 2017 - 8 AZR 845/15.

50. Specifically, Federal Labour Court of 10 July 2008 - 2 AZR 1111/06: Dismissal Protection Act 'primarily a grandfathering law and not a severance pay law'.

51. Federal Labour Court of 23 June 2005 - 2 AZR 256/04

52. Section 9(1) sentence 1 of the KSchG. Pursuant to section 10(1) of the KSchG, an amount of up to twelve months' earnings is to be fixed as severance pay.

53. Section 9(1) sentence 2 of the KSchG

54. Section 14(2) sentence 1 of the KoschG, though not providing a legal definition, makes reference to managing directors and operations managers. require any motivation. ${ }^{55}$ As a result, dismissal protection of executive employee is weaker than that of others employees.

\section{Social security in case of unemployment}

Under section 136(1) no. 1 SGB III, employees are entitled to unemployment benefits in the event of unemployment due, for instance, to dismissal. The duration of the entitlement to unemployment benefits depends on the duration of employment and the age of the unemployed person at the time the entitlement arises (section 157(1) SGB III). Thirty months of employment, for instance, result in a claim for fifty months. In cases where the unemployed person has at least one child or his/her spouse (civil partner) has a child, if both spouses are subject to unlimited income tax and are not permanently separated, the claim to unemployment benefits amounts to $67 \%$, and in other cases to $60 \%$ of the lump-sum net remuneration.

It should also be noted that severance pay or compensation for dismissal leads to the suspension of unemployment benefits if the employment relationship was terminated prematurely, i.e. at a time when the employer could not have terminated it unilaterally. According to section 158(1) sentence 1 SGB III, if the employee has received or is entitled to a severance payment, compensation or similar benefit (redundancy payment) due to the termination of the employment relationship and the employment relationship has been terminated without observing a period of notice corresponding to the employer's ordinary period of notice, the entitlement to unemployment benefit is suspended from the end of the employment relationship until the day on which the employment relationship would have ended if this period had been observed.

\section{Conclusion}

Perhaps the most interesting features of German employment protection law are its anchoring in fundamental rights on the one hand and, related to this, the important role of the courts on the other. In substance, the following should be emphasized: the importance of the principle of proportionality (in all its manifestations), the orientation toward the goal of achieving justice in individual cases, the limited judicial review of entrepreneurial decisions, and the special features of 'social selection'. The relatively strong position of works councils also appears to be significant.

55. According to section 25a of the Banking Act (Kreditwesengesetz, KWG), which came into force on 29 March 2019, section 9 (1) sentence 2 of the Dismissal Protection Act shall also apply to certain groups of bank employees with a high income. 
It is also noteworthy that the enforcement of protection against dismissal in Germany is largely in the hands of the courts. Preventive protection against dismissal (by state authorities) exists only in a few exceptional cases.

About twenty years ago, there was a sometimes heated discussion about whether the KSchG, which formally aims to protect the continued existence of the employment relationship, should be replaced by a law that only holds out the prospect of severance pay to the terminated employee from the outset. This discussion has never completely died down. However, it has calmed down considerably. Today, other issues are being discussed: the relationship between protection against dismissal and discrimination law, for example, but also the meaningfulness of a concept in which protection against dismissal - despite the dominant role of KSchG - is ultimately spread over various laws, which is criticized by some as excessive and too complicated. ${ }^{56}$ 